\title{
SOME ASPECTS ON FORMING PREPAREDNESS OF LOGISTICS MILITARY OFFICERS FOR MANAGEMENT ACTIVITIES
}

\author{
Venelin Terziev ${ }^{1}$ and Nikolay Nichev ${ }^{2}$ \\ ${ }^{1}$ Professor, Ph.D., D.Sc. (National Security), D.Sc. (Ec.), University of Rousse, Rousse, Bulgaria; \\ National Military University, Veliko Tarnovo, Bulgaria; University of Telecommunications and Post, \\ Sofia, Bulgaria, terziev@skmat.com \\ ${ }^{2}$ Colonel Associated Professor, Ph.D., National Military University, Veliko Tarnovo, Bulgaria, \\ nicheff@gmail.com
}

\begin{abstract}
The profession of military service officer is regarded by the society as a part of professional fulfilment in life imposed the execution of the profession by making rational management decisions and possessing a high degree of competence and skills in modern management of military teams. The officer is a leader with undivided personal authority, who takes full responsibility for the training and combat readiness of the personnel from the military unit entrusted to him. The training and education of cadets at the Vasil Levski National Military University is directed towards professional, intellectual, physical and moral development, and creation of leadership and management skills. They are focus on forming knowledge, skills, and moral and volitional qualities.

It can be noticed a trend of increasing graduates from the Vasil Levski National Military University with inadequate training in modern military management. Therefore, a priority task of the management and academic staff of the Vasil Levski National Military University and at the same time - one of the main directions for scientific research must be to increase the preparedness of the future logistics officers for management activities.
\end{abstract}

Keywords: military training, training of cadets

\section{INTRODUCTION}

The profession of military service officer is regarded by the society as a part of professional fulfilment in life imposed the execution of the profession by making rational management decisions and possessing a high degree of competence and skills in modern management of military teams. It can be noticed a trend of increasing graduates from the Vasil Levski National Military University with inadequate training in modern military management. Therefore, a priority task of the management and academic staff of the Vasil Levski National Military University and at the same time - one of the main directions for scientific research must be to increase the preparedness of the future logistics officers for management activities. 


\section{ESSENCE OF THE PREPAREDNESS FOR MILITARY SERVICE MANAGEMENT OPERATIONS}

V. Madansky presents the preparedness as a complex multi-level education and a dynamic system involving cognitive, volitional, motivational, emotional and meaningful performance of the activity. (2016)

In a narrow sense preparedness can be presented as a state of the mobilisation of all psychophysical systems of the human being, ensuring effective performance of certain actions. In a broad sense it can be presented as a combination of professionally-driven requirements to a man. The preparedness for activity is traditionally studied by military psychology, sports psychology and psychology of labour.

There are different scientific approaches to the concept of preparedness. Studying preparedness for professional activities it can be pointed three of them building upon the specifics of the tasks which must be solved: psycho-physiological, functionally-psychological and individual.

According to the psychophysiological approach the preparedness is the optimal state of mental and physiological functions of the body, allowing performing a specific occupation. The preparedness, as a kind of state of the individual, cannot arise out of the total brain activity and activity of the different human systems and organs. It requires some biochemical and physiological changes in human body which provide personal adaptation to upcoming activities.

The functionally-psychological approach studies the compatibility of the psychological qualities of a personality to the functional characteristics of professional activity. Some psychological conditions of preparedness for implementing specific activities are: understanding, taking responsibility, desiring success, determining the sequence and methods of action.

The individual approach emphasizes the role of the cognitive processes, emotional and volitional components of the human behaviour, and its reasons.

The terms "training" and "preparedness" are not synonyms, but they are interrelated and mutually conditioned. The level of preparedness is largely determined by the passed training. The term "preparation" means a dynamic process, the ultimate goal of which is the formation of the status of preparedness for activities. The preparedness for actions can be defined as: active state of the individual which incites activity; result of operations; professionally important quality; stable feature of personality; prerequisite for purposeful activity, for its regulation, sustainability and efficiency.

Based on the theoretical reviewed approaches and those addressed to the problem of formation of professional preparedness for different types of activity, V. Madansky concludes that the professional preparedness cannot be presented only as a process and result, but as a primary and fundamental condition for the effective realisation of personal abilities and as a systematic connection of personal qualities and the expertise of specialists, formed with taking into account the requirements of upcoming activities. According to him the preparedness is primarily an active-operatively status of the individual, which reflects the content of upcoming tasks and conditions for their implementation. The author does not oppose it to the understanding of preparedness as mental condition and quality of personality. In both cases, the preparedness is a prerequisite for efficient operations.

Considering the fact that the graduates in military specialization „Material resources, movement and transportation" are well-prepared in Leadership and intellectually, morally, physically and professionally prepared to exercise the regulated profession „Officers at the Tactical Level of Management” as officers of the logistical structures of the Bulgarian Army, (2016P) it could be concluded that the preparedness of the future officers for military management activities is central to the military training at the Vasil Levski Military University. That requires analysing military management activity and the characteristics of the logistics officer's military management activity.

\section{MILITARY MANAGEMENT ACTIVITY}

According to K. Todorkov, military management activity is a special kind of human activity, the main feature of which is that it is directed to other people. (1998) The profession of a commander of military formation represents a kind of management activity. In essence, it is a comprehensive impact for coordinating joint actions of the individual (officers, sergeants, and soldiers), groups and collectives to meet the specific military obligations and tasks which stand to solve and are dictated by specific purposes of the army.

This activity has a number of specific characteristics and requirements directed to the commander.

The military managerial activity is interaction between the commander and the military staff (groups and categories of people), which includes different types of contacts: 
a) Directive - giving orders, post-provision of tasks, assignments;

b) Pedagogical - teaching, training, giving instruction;

c) Collective - developing joint plans and solutions, conferences;

d) Controlling - monitoring actions of subordinates, accepting of statements and reports;

e) Operational-complex in terms of direct impacts on people during the execution of a task, etc.

In the process of military service, the military management activity is characterized by large volumes of various mental tasks, limitations in the terms of their solution, dangerous consequences of wrong decisions and actions. Management tasks are so interrelated that in solving one of them is necessary to consider a number of others, so do not cause any harm. This requires a high level of responsibility and tension in the entire activity of the commander, raises specific management difficulties, whose essence is in the need to find such a solution to put things in order and ensure the implementation of the entire set of the upcoming tasks.

The military management activities of a serviceman can be conditionally divided into performing general management and special functions. (1998)

General management functions include:

- conducting national policy for the armed defence of the country in life and work of the managed formation;

- defining objectives and main lines of the activity of the team management in accordance with the tasks set by higher authorities;

- creating a cohesive, disciplined, efficient team of warriors with different functional responsibilities, functions, and experience;

- optimal allocating all functional responsibilities, forces and resources within the collective.

Special functions comprise:

- clarifying the tasks arising from regulatory documents placed by the senior authorities;

- determining the ways and means of accomplishing the tasks considering the abilities of the military team (composition, qualifications, experience, etc.);

- decision-making and setting tasks for subordinates;

- providing the necessary conditions for solving tasks;

- guiding the activities of subordinates, coordination of actions between team members, monitoring implementation and giving additional tasks;

- manoeuvring the reserve;

- evaluating the final results of the implementation of tasks.

The objects of the management are the following functions: forecasting, organisation, management, coordination and controlling. The decision-making process, coordination and building links are essential for the realization of these functions.

Generally, the commander's activity is determined by two factors. The first factor is military factor, which is related to the common organisation of the activity and the other factor is orientated to the organisation of cyclically recurring training and combat, service, household and other tasks. This means that the management activity of the commander is universal and represents a continuously solving of tasks from different type and complexity. This activity has some general psychological characteristics as follows:

- social nature, connected with the management of various communities of people;

- large volume and variety of operational tasks and actions;

- not-algorithmically nature of many management actions, which is associated with a certain lack of information in terms of frequently changing environment and working conditions;

- strong determination of operational activities over time;

- high psychological tension associated with greater responsibility for the adoption of decisions and results of the activity of the staff. 


\section{SPECIFICATIONS OF THE MILITARY MANAGEMENT ACTIVITIES OF THE LOGISTICS OFFICER}

Many researchers share the view that the main feature of the logistic officer in modern conditions appears to be his ability effectively to manage logistic units in accordance with the constantly changing social, economic, and social conditions. The modern logistics officer performs management activities as a commander of the Armed Forces of the Republic of Bulgaria and must possess the qualities as: managerial competence in various economic and legal issues, communication skills, tolerance, constructiveness, responsibility, i.e. a set of qualities that defines him as a "manager", "leader" and "officer“", (2015), (2017a), (2017b).

The military management activity of the logistics officer is determined by its goals. The logistics officer prepares orders and activity plans of the superiors and commanders; predicts deadlines, methods, and assets for the implementation of the tasks that stood before him; formulates and specifies the obligations of subordinates; and determines the personal involvement in this complex and interconnected process on the base of the regulating documents. The result of these actions is ensuring appropriate conditions for active work of the staff which performs the general ideas of the warrior activities. Therefore, the objective of the management activity of the logistics officer is to create a set of conditions necessary for the preparation and implementation of purposeful activity (in its various types) for the implementation of the logistical tasks with his personal effort. The orders, instructions, requirements from superior command, the tasks of military formation which are specified by the commander, the idea of action, the level of training subordinate officers, sergeants, soldiers and civil persons affect the formulation of goals in particular circumstances.

According to Nichev and Petrova the military management activity as a system is based on the relevant motives which are formed as a result of the realization of military management goals, personal management skills, acquired and developed managerial skill, and interests. (J2015)

Primarily, the main reasons for management activities are the military professional beliefs of the logistics officer, his moral principles, sense of personal responsibility for everything that concerns the life and work of the team, which he manages. The specific management motivation, developing on the basis of realization of the managerial skills forms propensity to management activities. The realization of the fact that the officer should be more useful to the society and himself into the army, and can uncover and develop his abilities is a powerful permanent internal motive for management activities and enhancing mastery.

The military team as a specific social system has a special integrative element - unity of the command which institutional side is reflected in a single command body and personality - in the principles of individual command. (1998) On the one hand, the individual command in the army is a principle that lays the foundation of management activity of the logistics officer, and on the other hand, allows to the logistics officer to work creatively.

The military management activity of the majority of the officers in the Bulgarian Army is limited in the military socium. It is a process of performing the tasks of a military service, studying military equipment and weapons, performing combat duty, warfare against enemy, etc. (1994) The military management activities of logistic officers are connected with cooperation with government bodies, NGOs, local authorities and various business organizations.

\section{CONCLUSION}

The military management activity of the logistic officers is subject to unconditional execution of the orders of the commander and direct supervisor, arising from individual command in the army, in accordance with the requirements of the current legislation.

It is strictly regulated in the Statute for the Military Service in the Armed Forces of the Republic of Bulgaria and into the job description for the professional position. Therefore, any innovative management decision should be seen as ways for improving command duties but not as scheduled commitments on default.

\section{REFERENCES LIST}

Angelov, H., (1994). Psychological Problems of Military Activity, Publishing House of the Ministry of Defence.

Madansky, V., (2016). Fundamentals of the Survival in Extreme Conditions of Military Professional Activity, Dissertation for acquiring the degree of Doctor of Science, Veliko Turnovo, Bulgaria. 
Nichev, N., Foundations of Military Theoretical Logistics - Organisation of Logistical Support, Vasil Levski National Military University, V. Tarnovo, Bulgaria.

Nichev, N., Petrova, E. (J2015) Professional Training of Future Logistic Officers at National Military University of Bulgaria. Sibiu, Romania, The 21st International Conference The Knowledge-Based Organisation, Nicolae Balcescu Land forces Academy.

Petrova, E., (2015) Leadership and Power in Large Social Groups, Revista Academiei Fortelor Terestre, NR. 1 (77) / 2015.

Qualification Characteristics for Training for the specialty of regulated profession Organisation and Management of Military Units at the Tactical Level with military qualification Officer for Tactical Level of Command at the Vasil Levski National Military University: Academic Plan 1-5-16. (2016P)

Terziev, V., Nichev N., (2017a). Research of the motivation for management activities of cadets in the course of their military professional training. Scientific journal „Economics and finance“, Topical questions of contemporary science, Aspekt Publishing, Taunton, MA, United States of America.

Terziev, V., Nichev N., (2017b). Research of the value orientation and structural peculiarities of management activities of cadets in the course of military professional training. Scientific journal „Economics and finance", Topical questions of contemporary science, Aspekt Publishing, Taunton, MA, United States of America.

Todorkov, K. (1998). Psychological Aspects of Management Activity of the Commander, Ministry of Defence. 